\title{
POLITENESS STRATEGIES USED BY AN ENGLISH \\ TEACHER IN THE CLASSROOM AT MTS SWASTA \\ AL-JIHAD MEDAN
}

\author{
*Jumita Sari \\ **Dr. Rahmad Husein, M.Ed. \\ **Syamsul Bahri, S.S., M.Hum.
}

\begin{abstract}
Sari, Jumita. 2123121023. Politeness Strategies Used by an English Teacher in the Classroom at MTs Swasta Al-Jihad Medan. A Thesis: English Department. Faculty of Languages and Arts. State University of Medan. 2017.
\end{abstract}

This study aimed at investigating types of politeness strategies used by an English teacher in the classroom, and to describe the reasons politeness strategies realized by English teacher in the classroom. This study was conducted by applying descriptive qualitative research. The source of the data was an English teacher of class VIII in MTs Swasta Al-Jihad Medan. The researcher used random sampling technique. The instruments of this study were interview and video recording. The data were analyzed using data descriptive. The findings of the result were that: (1) There were three of politeness strategies, namely: Bald on Record (38.1\%), Positive Politeness (33.33\%), and Negative Politeness (28.57\%) and Off Record (0\%). (2) Bald on Record was realized because it made close relationship between teacher and students, Positive Politeness was realized because to give respect to the students during teaching learning process, Negative Politeness was realized to maintain closer friend among them, and Off Record never realized by English teacher during teaching learning process.

Keywords: Politeness, Politeness Strategies, and Roles of Teacher.

*Graduate Status
$* *$ Lecturer Status 


\section{INTRODUCTION}

\section{Background of the Study}

Politeness is a universal and best expressed as the practical application of good manners or etiquette. Leech (1993) is quoted by Manik \& Hutagaol (2015) defines it as "strategic conflict avoidance, which can be measured in terms of degree of effort and put into the avoidance of conflict, situation, maintenance and establishment of comity. The avoidance is represented as a conscious effort on part of the person to be polite. Brown \& Levinson (1987 cited in Zhang, 2009) is quoted by Manik \& Hutagaol (2015) state that politeness strategies are more likely to be used when a speaker of relatively lower power makes a larger request in a more distant relationship than when a speaker of relatively higher power makes a smaller request in a closer relationship. Manik \& Hutagaol (2015) state that politeness strategies are ways to convey the speech acts as polite as possible. To achieve that, there are some strategies that can be applied in specific context used by an individual in certain society especially in school. Specifically classroom is the setting where politeness is educated and where the relationship between teacher and students should be well established. It must be effective and polite.

From the very beginning of language study, classrooms should be interactive. Rivers (1987: 4-5) puts it this way that through interaction, students can increase their language store as they listen to or read authentic linguistic material, or even the output of their fellow students in discussions, skits, joint problem-solving tasks, or dialogue journals. In interaction, students can use all 
they possess of the language-all they have learned or casually-in real-life exchanges. Even at an elementary stage, they learn in this way to exploit the elasticity of language.

Classroom is a place of process teaching and learning activity, teachers' language plays a very important role in EFL classroom, such as teachers' academic instructions, motivating the class and evaluating students. No exaggeration to say that teachers' language is indispensable to effective communication in class. Harmer (2001: 3) states that the way that teachers talk to students - the manner in which they interact with them - is one of the crucial teacher skills, but it does not demand technical expertise. It does, however, require teachers to empathies with the people they are talking to. One group of people who seems to find it fairly natural to adapt their language to their audience is parents when they talk to their young children. Studies show that they use more exaggerated tones of voices, and speak with less complex grammatical structures than they would if they were talking to adults. Their vocabulary is generally more restricted too and the attempt to make eye contact (and other forms of physical contact) is greater. They generally do these things unconsciously.

In education, teachers were expected to play vital roles in the lives of the students in their classrooms. Teachers are best known for the role of educating the students that are placed in their care. As supported by Nuh (2012) quoted by Manik and Hutagaol (2015), the education minister of Indonesia, asserts that politeness of Indonesian students is in a state of decline. It means that a teacher has a responsibility to teach their students how to speak politely and admonish 
them if they speak impolitely at school especially during classroom interaction. Moreover, a teacher also needs to speak politely in front of the students in order to influence them to speak politely too. In addition, the implementation of politeness strategy is relevant which curriculum 2013 which emphasize on good character because politeness strategy deals with someone's ability to show his good character. Therefore, the teacher is obliged to implement it in the language learning activities along with language usage.

However, based on researcher's observation of teachers' utterances at MTS Swasta Al-jihad, it is not as expected. The teacher used impolite utterances to their students and the impolite utterances affected to students' compliances during English teaching learning process. For example, students: (when the students make a noisy), Teacher: “hey, kalian diam la!". For the teacher's utterances above has shown impolite to ask student calm down. Another example, Teacher: "dengarkan dulu, dengarkan! Ini bukan taman kanak-kanak ya!." That command has shown impolite to junior student, be better the teacher used another word to create good situation as "anak-anak, ibu lagi menjelaskan pelajaran, suaranya tolong ya" or "tolong jangan berisik ya". To create collaborative between teacher and students so must create good situation and interaction among them because the role of teacher as a good model for the student where the teacher still use the violence as the effective way to control students. If the class interaction goes well, the knowledge that is given by the teachers will be received well by the students. 
Fraser (1983: 30) is quoted by Adel Davoudi and Ramezanzadeh (2016) describes that pragmatic competence functions as the knowledge of how an addressee determines what a speaker is saying and recognizes intended illocutionary force conveyed through subtle attitudes. Without this knowledge, there are cases where interlocutors cannot understand each other and failure in communication occurs. One important aspect of pragmatic competence is politeness. Peng,Xie and Cai (2014) states that Brown and Levinson (1978) formulate four politeness strategies and analyze four strategies: bald on record (without any redressive action), positive politeness (solidarity-seeking), negative politeness (freedom-given), and off record (indirect).

Based on explanation above about politeness strategies, so the researcher was interested in investigating politeness strategies used by an English teacher in the classroom. This study will describe politeness strategies used by English teacher at MTS Swasta Al-jihad.

\section{REVIEW OF LITERATURE}

Watts (2003: 13) states that theory of politeness; the term is used almost exclusively to refer to the different ways of conceptualizing politeness. But doing this only clouds the issue, since polite and politeness are lexemes in the English language whose meanings are open to negotiation by those interacting in English.

Yule (1996) is quoted by Manik \& Hutagaol (2015) states that politeness is an interaction, it can be defined as the means employed to show awareness of another person's face. In this sense, politeness can be accomplished in situations 
of social distance or closeness. Showing awareness for another person's face when that other seems socially distant is often described in terms of respect or deference.

Manik \& Hutagaol (2015) states that Politeness strategies are more likely to be used when a speaker of relatively lower power makes a larger request in a more distant relationship than when a speaker of relatively higher power makes a smaller request in a closer relationship (Brown \& Levinson, 1987 cited in Zhang, 2009). Politeness strategies are ways to convey the speech acts as polite as possible. To achieve that, there are some strategies that can be applied in specific context used by an individual in certain society. Based on Brown and Levinson theory, there are four politeness strategies consist of: Bald on Record, Positive Politeness Strategies, Negative Politeness Strategies, and Off Record Politeness Strategies.

Brown and Levinson (1987) is quoted by Dewi (2015) state that there are some motives that cause someone to use a politeness strategy when he communicate with others. Usually, the motives consider three elements, namely the social distance (D) of the speaker and addressee, the relative power (P) between them and the absolute ranking of imposition $(\mathrm{R})$ in particular culture. It means that someone should choose an appropriate strategy in accordance with what he is going to say and to whom he speak.

Brown (2000: 166-168) states that teachers can play many roles in the course of teaching. Just as parents are called upon to be many things to their children, teachers cannot be satisfied with only one role. Rebecca Oxford et al 
(1998) pointed out that teacher roles are often best described in the form of metaphor: teacher as manufacturer, teacher as doctor, teacher as judge, teacher as gardener, and others. Following you will find another set of metaphors to describe a spectrum of possibilities of teacher roles, some of which are more conducive to creating an interactive classroom than others.

\section{RESEARCH METHODOLOGY AND FINDINGS}

\section{Methodology}

This study applied descriptive qualitative research, which is basically interpretative research to purposefully select informants either people, documents or visual materials that might be the best answer to the research problem. The design was used to find politeness strategies used by an English teacher in classroom. Qualitative research focuses on understanding social, phenomena, and providing rich verbal descriptions of setting, situations, and participants (Ary, Jacobs, Sorensen, Razavieh, 2010:39).

Descriptive qualitative research describes the various pertinent aspects of the study including: the setting, both temporally and physically; the individuals being studied; the purpose of any activities examined; the viewpoints of participants; and the effects of any activities on the participants (Best \& Khan, 2002:203). This types of this research was case study. Case study is a type of ethnographic research study that focuses on a single unit, such as one individual, one group, one organization, or one program (Ary, Jacobs, Sorensen, Razavieh, 
2010:39). It was used to investigate the data which found in the field which contras to theory.

\section{Techniques of Data Analysis}

The data was used qualitative data analysis (Miles, Huberman, and Saldana, 2014:12). It was analyzed with three procedures, namely: 1) Data condensation, 2) Data display, and 3) conclusion drawing and verification.

\section{Data Condensation}

Data condensation refers to the process of selecting, focusing, simplifying, abstracting, and transforming the data that appear in written-up field notes or transcriptions. Here, the data was selected and the transcriptions of record observation done by the teacher in classroom were identified.

\section{Data Display}

Data display is an organized, compressed assembly of information that permits conclusion drawing and action. The data was designed to assemble organized information in an immediately accessible and compact form. The aim to see clearly what types of politeness strategies used by teacher and students in English classroom.

\section{Conclusion Drawing and Verification}

Conclusion is the analyst proceeds and verification is fleeting second thought crossing the analyst's mind during writing, with a short excursion back to the field notes, or it may be through and elaborate, with lengthy argumentation and review among colleagues to develop "intersubjective consensus". Conclusion 
drawn based on the result which is shown in the data display. Then, the conclusion verified by looking back on the field notes which the researcher has got during the observation.

\section{Findings}

After analysis of the data obtained in this study, it can be argued some of findings as follow:

1. There were three politeness strategies found during teaching learning process which used by an English teacher at MTS. Swasta Al-Jihad Medan, namely: Bald on Record, Positive Politeness, and Negative politeness. Specifically, 8 (38.1\%) for Bald on Record, 7 (33.33\%) for Positive Politeness, and 6 (28.57\%) for Negative Politeness.

2. Off Record was not found during teaching learning process and the teacher was not used this strategy; however in the last meeting she used it.

3. Politeness strategies used by an English teacher during teaching learning process was to describe that politeness is soften and polite language and it is very important applied in the classroom which can be a teacher produce polite generation. Furthermore, this strategy successful applies in the classroom during teaching learning process to know very well the character of the students. 


\section{CONCLUSIONS AND SUGGESTIONS}

\section{Conclusions}

Based on the researcher's findings, it is obtained some conclusions as follows:

1. There were three politeness strategies found during teaching learning process which used by an English teacher at MTS. Swasta Al-Jihad Medan, namely: Bald on Record, Positive Politeness, and Negative politeness. Specifically, 8 for Bald on Record, 7 for Positive Politeness, and 6 for Negative Politeness. And dominantly types of politeness strategies used by an English teacher at MTS. Swasta Al-Jihad were Bald on Record. It means that the teacher makes comfortable and enjoyable in her environment which makes the conversation close friend among them.

2. Politeness strategies used by an English teacher during teaching learning process was to describe that politeness is soften and polite language. And the teacher has a responsibility to teach their students how to speak politely at school especially during teaching learning process in the classroom. 


\section{Suggestions}

There are some contributions points suggested as the following:

1. For the linguist.

It is advisable to continue explore their knowledge relating to the special linguistics politeness especially politeness strategies in the classroom in order to contribute to development of the science of language.

2. For other researcher.

It is recommended to conduct research by expending the study on others literature to obtain new findings specifically related to politeness strategies.

3. For the teachers.

The teacher who have directly involved to the classroom and the teaching learning process at school are suggested to apply this politeness strategies which put impact student's attitude and behavior.

4. For the sociolinguistics lectures.

It is advisable to increase development of linguistics politeness theories so that they can inform and share to the students when teaching politeness.

5. For the government.

It is advisable to give some considerations about the importance of implementing politeness strategies in National Curriculum which emphasize on good character. 


\section{REFERENCES}

Adel, S. M. R, Davoudi, M, Ramezanzadeh, A. 2016. A Qualitative Study of Politeness strategies used by Iranian EFL Learners in a Class Blog.Urmia University: Iranian journal of Language Teaching Research 4(1), 47-62.

Ary, D, Jacobs, L. C, Sorensen, C, Razavieh, A. 2010.Introduction to Research in Education: $8^{\text {th }}$ edition. Canada: Wadsworth.

Brown, H. D. 2000. Teaching by Principles an Interactive Approach to Language Pedagogy: Second edition. San Francisco, California: Longman.

Best, J. W. \& Khan, J. V. 2002.Research in Education: $7^{\text {th }}$ edition. Prentice-Hall: New Delhi.

Brown, P. \& S. C. Levinson. 1987. Politeness Some Universals in Language Usage. Cambridge: Cambridge University Press.

Dewi, K. 2015. Politeness Strategies Used by Teachers and Students in Directive Speech Acts in Classroom Interaction.State University of Medan.

Fraser, B. 1983.The Domain of Pragmatics, In:J, Richards and R, Schmidt (Eds), Language and Communication. New York: Longman, 29-59.

Harmer, J. 2001.How to Teach English. London: Longman.

Leech, G. 1993. Prinsip-PrinsipPragmatik. Jakarta: UniversitasIndonsia Press.

Malamah-Thomas, A. 1987.Classroom Interaction. Oxford: Oxford University Press.

Manik, S. \&Hutagaol, J. 2015.An analysis on Teacher's Politeness Strategy and Student's Compliance in Teaching Learning Process at SD Negeri 024184 BinjaiTimurBinjai-North Sumatra-Indonesia. Language and Arts Faculty: HKBP Nommensen University; Vol.8, No.8.

Miles, M. B, Huberman, A. M, Saldana, J. 2014.Qualitative Data Analysis: A Methods Sourcebook 3rd edition. Baverly Hills, CA: Sage.

Peng, L, Xie, F, Cai, L. 2014. A Case Study Of College Teacher's Politeness Strategy in EFL Classroom. Academy Publisher: Finland. Theory and Practice in Language Studies, Vol.4, No.1, pp. 110-115. 
Rivers, W. M. 1987. Interactive Language Teaching. Cambridge: Cambridge University Press.

Watts, R. J. 2003. Key Topics in Sociolinguistics Politeness. Cambridge: Cambridge University Press.

Yule, G. 1996. Pragmatics. Cambridge: Cambridge University Press. 